\title{
Placental Growth Factor Level is Lower in Early-Onset Preeclampsia, while Tumor Necrosis Factor Alpha Level does not Show any Difference between Early and Late Onset Preeclampsia
}

\author{
Kadar Placental Growth Factor lebih rendah pada Preeklampsia Awitan Dini, \\ sementara tidak ada Perbedaan Kadar Tumor Necrosis Factor Alpha \\ pada Preeklampsia Awitan Dini dan Lambat
}

\author{
Christofani Ekapatria, Udin Sabarudin, Sonny Sasotya \\ Department of Obstetrics and Gynecology \\ Faculty of Medicine University of Padjadjaran/ \\ Dr. Hasan Sadikin Hospital \\ Bandung
}

\begin{abstract}
Objective: To analyze the difference of PlGF and TNF- $\alpha$ serum level between early-onset and late-onset preeclampsia.

Method: This is a cross-sectional analytic comparative study comparing serum level of PIGF and TNF- $\alpha$ between groups with earlyand late-onset preeclampsia. Each group consists of 32 subjects who met inclusion criteria and presented to Dr. Hasan Sadikin Hospital or its district hospitals in September - November 2012. Statistical analysis was performed with Kolmogorov Smirnov test, SaphiroWilk test, and non-parametric Mann-Whitney test.

Result: Mean of PlGF serum level in the group with early-onset preeclampsia is $53.0344 \pm 38.07140 \mathrm{pg} / \mathrm{ml}$, while mean of which in the group with late-onset preeclampsia is $241.8063 \pm 192.8373 \mathrm{pg} / \mathrm{ml}$ $(\mathrm{p}<0.0001)$. Mean of TNF- $\alpha$ serum level in the group with early-onset preeclampsia is $2.7733 \pm 0.97533 \mathrm{pg} / \mathrm{ml}$, while mean of which in the group with late-onset preeclampsia is $2.5061 \pm 0.84872 \mathrm{pg} / \mathrm{ml}$ $(\mathrm{p}=0.235)$.
\end{abstract}

Conclusion: Serum level of PlGF in early-onset preeclampsia is lower than the level of which in late-onset preeclampsia $(\mathrm{p}<0.0001)$. There is no significant difference of TNF- $\alpha$ serum level between the early- and late-onset preeclampsia $(\mathrm{p}=0.235)$.

[Indones J Obstet Gynecol 2012; 36-4: 181-4]

Keywords: early onset, late onset preeclampsia, PlGF, preeclampsia, TNF- $\alpha$

\begin{abstract}
Abstrak
Tujuan: Menganalisis perbedaan kadar PIGF dan TNF- $\alpha$ antara preeklampsia awitan dini dan lambat.

Metode: Penelitian dilakukan dengan metode analitik komparatif dengan metode potong lintang yang membandingkan kadar PlGF dan $T N F-\alpha$ antara kelompok preeklampsia awitan dini dan lambat. Subjek penelitian pada setiap kelompok berjumlah 32 pasien yang memenuhi kriteria inklusi dan datang berobat ke RSUP Dr. Hasan Sadikin Bandung serta rumah sakit jejaring yang ditunjuk pada bulan September - November 2012. Analisis statistik dilakukan dengan uji Kolmogorov Smirnov, uji Saphiro-Wilk, dan uji non-parametrik Mann-Whitney.

Hasil: Rerata PIGF serum pada kelompok preeklampsia awitan dini adalah 53,0344+38,07140 pg/ml sedangkan pada kelompok preeklampsia awitan lambat adalah 241,8063 $\pm 192,8373 \mathrm{pg} / \mathrm{ml}(p<0,0001)$. Rerata TNF- $\alpha$ serum pada kelompok preeklampsia awitan dini adalah $2,7733 \pm 0,97533 \mathrm{pg} / \mathrm{ml}$ sedangkan pada kelompok preeklampsia awitan lambat adalah 2,5061 $\pm 0,84872 \mathrm{pg} / \mathrm{ml}(\mathrm{p}=0,235)$.

Kesimpulan: Kadar PIGF pada preeklampsia awitan dini lebih rendah daripada preeklampsia awitan lambat $(p<0,0001)$. Tidak ditemukan perbedaan yang bermakna pada kadar TNF- $\alpha$ antara preeklampsia awitan dini dan lambat $(p=0,235)$.
\end{abstract}

[Maj Obstet Ginekol Indones 2012p; 36-4: 181-4]

Kata kunci: PIGF, preeklampsia awitan dini, preeklampsia awitan lambat, $T N F-\alpha$

Correspondence: Christofani Ekapatria, Jln. Teluk Peleng no 62A Pasar Minggu Jakarta Selatan, Telephone: 08122188611, Email: christoekapatria@yahoo.com

\section{INTRODUCTION}

Preeclampsia is a pregnancy-specific syndrome, which increases morbidity and mortality of both mother and fetus, and it is responsible for $4-8 \%$ of pregnancy complications. Based on the onset, ACOG (American College of Obstetrics and Gynecology) classified preeclampsia in two groups: early onset preeclampsia for those occurred before the $34^{\text {th }}$ gestational week, and late onset preeclampsia for those occur after the $34^{\text {th }}$ gestational week. ${ }^{1}$ This classification is made according to the significant differences in fetomaternal outcome of both groups. ${ }^{1,2}$ Immunological, genetic, biochemical, and inflammatory factors are still discussed as the underlying mechanisms of preeclampsia. ${ }^{3-5}$

Placental growth factor is pregnancy specific hormone involved in trophoblastic invasion and fetal growth. This hormone is first detected in the fifth gestational week, the level of which keeps rising with placental growth. However, this does not occur in pregnancy complicated by preeclampsia. ${ }^{6,7}$ PIGF level is a dependable marker to predict preeclampsia. $^{2,}$ 8-10 
TNF- $\alpha$ induces vasoconstriction, and is involved in micro vascular protein leakage and hypertriglyceridemia. ${ }^{11}$ Rise in TNF- $\alpha$ level is found in patients with preeclampsia. ${ }^{11-14}$

No study has reported comparison of angiogenic factor (PlGF) and inflammatory factor (TNF- $\alpha$ ) between early onset and late onset preeclampsia in Indonesia. This is seen as an interesting topic, as the result would bring us closer to understand more about some factors to predict preeclampsia.

\section{METHOD}

This was a cross-sectional analytic comparative study, comparing serum level of PlGF and TNF- $\alpha$ between groups with early and late onset preeclampsia. Each group consisted of 32 subjects with gestational age of 20 weeks or more, single live fetus, who regularly have antenatal care, not showing any signs of infection, and clinically diagnosed with preeclampsia before and after the $34^{\text {th }}$ gestational week from the last menstrual period, not having any history of hypertension nor kidney or liver disorder before pregnancy, and presented to Dr. Hasan Sadikin Hospital or its district hospitals in September - November 2012.

Five ml of blood sample were collected by cubital vein phlebotomy. The blood was stored for \pm 30 minutes in vacutainer, to be centrifuged in 3000 rpm thereafter for 10 minutes. The serum were stored in plastic tubes at $-20^{\circ} \mathrm{C}$. Then the serum level of PIGF and TNF- $\alpha$ were measured by ELISA method. The results recorded were serum level of PIGF in $\mathrm{pg} / \mathrm{ml}$ and serum level of TNF- $\alpha$ in $\mathrm{pg} / \mathrm{ml}$.

\section{RESULT}

Characteristics of subjects in both groups are analyzed by Mann-Whitney test for numerical data and Kolmogorov-Smirnov test for categorical data. They are maternal age (in categories of $<20$ year old, 20-35 year old, and $>35$ year old), parity (in categories of $0,1-3$, and $4+$ ), and BMI before pregnancy (with mean of $22.2538 \pm 1.19469$ in subjects with early-onset preeclampsia, and 23.1509 \pm 1.90633 in those having late-onset preeclampsia). Both groups do not show any significant difference in maternal age $(p=0.627)$, parity $(p=1.000)$, or BMI before pregnancy $(\mathrm{p}=0.073)$.
Saphiro-Wilk test for normality was done on the PIGF and TNF- $\alpha$ serum level from the 64 subjects. $p$ value of $<0.05$ shows the data from both groups are not normally distributed. Thus, the data was analyzed with Mann-Whitney nonparametric test. SPSS version 18.0 for windows was used in analyzing data.

Table 1. Comparison of PIGF serum level between early onset and late onset preeclampsia

\begin{tabular}{lccc}
\hline \hline \multirow{2}{*}{$\begin{array}{c}\text { PIGF } \\
\mathbf{( p g} / \mathbf{m l})\end{array}$} & \multicolumn{2}{c}{ Group } & \multirow{2}{\mathbf{p}}{} \\
\cline { 2 - 3 } & $\begin{array}{c}\text { Early onset pre } \\
\text { eclampsia (n=32) }\end{array}$ & $\begin{array}{c}\text { Late onset pre } \\
\text { eclampsia (n=32) }\end{array}$ & value \\
\hline Mean & 53.0344 & 241.8063 & $<0.0001^{*}$ \\
SD & 38.07140 & 192.8373 & \\
\hline \hline
\end{tabular}

Note: *Mann-Whitney test

Table 2. Comparison of TNF-a serum level between earlyonset and late-onset preeclampsia

\begin{tabular}{|c|c|c|c|}
\hline \multirow{2}{*}{$\begin{array}{c}\text { TNF- } \alpha \\
\text { serum level } \\
\text { (pg/ml) }\end{array}$} & \multicolumn{2}{|c|}{ Group } & \multirow{2}{*}{$\begin{array}{c}\mathbf{p} \\
\text { value }\end{array}$} \\
\hline & $\begin{array}{c}\text { Early onset pre } \\
\text { eclampsia (n=32) }\end{array}$ & $\begin{array}{c}\text { Late onset pre } \\
\text { eclampsia (n=32) }\end{array}$ & \\
\hline Mean & 2.7733 & 2.5061 & $0.235^{*}$ \\
\hline SD & 0.97533 & 0.84872 & \\
\hline
\end{tabular}

Note: *Mann-Whitney test

Table 1 shows PIGF serum level of the group with early-onset preeclampsia compared with lateonset preeclampsia. The level is significantly lower in the group with early onset preeclampsia. Whereas Table 2 shows a nonsignificant result ( $p>0.05$ ), therefore TNF- $\alpha$ serum level of both groups is not significantly different.

\section{DISCUSSION}

The two-stage model of preeclampsia proposes that the first stage of preeclampsia is dominantly caused by poorly perfused placentation. This condition explains the lower PIGF level in the early onset compared with late onset preeclampsia, where greater extent of placental damage takes place. ${ }^{15} \mathrm{~A}$ study done by Ogge in 2011 explained that placental damage in early onset preeclampsia is histopathologically more extensive due to the greater degree of lesion following the wider infarction, and chronic inflammation such as vasculitis and villitis, which causes decidual arteriopathy and further re- 
duction of villi surface volume. In early onset preeclampsia, trophoblastic inadequate invasion to maternal spiral artery accounts for reduced perfusion to umbilical artery, which causes fetal restriction. ${ }^{16}$ The significantly different level of PlGF shown in this study may be affected by some factors, one of them is the very low level of which in early onset preeclampsia may follow more damage in placenta, although histopathological examination was not performed in this study. Furthermore, the PlGF serum level in late onset preeclampsia is higher, some approaching the level of which in normal pregnancy, because of the minimally damaged or even intact placenta.2,16,17 Compared with the other angiogenic factors, PIGF serum level is superior for detecting preeclampsia, as PIGF is placental specific. ${ }^{15,18}$

This study reports a non-significant difference in TNF- $\alpha$ serum level. This result can be explained by theory of pathogenesis proposed by Roberts, in which endothelial dysfunction following the increased level of cytokine, such as TNF- $\alpha$, is the second stage of preeclampsia. Placental abnormalities in the first stage may induce release of placental factors into maternal circulation. This leads to glomerular endotheliosis, vascular permeability, and inflammatory response marked by increased level of cytokines such as TNF- $\alpha$, further causing various organ damage by mechanism of hypoperfusion. ${ }^{15}$ According to former studies by Ogge and Huppertz, placental abnormality in preeclampsia may have occurred in the first trimester, even when clinical manifestations are not observable yet, leaving a more extensive placental damage. ${ }^{16,17}$ Earlier hypoxia condition happened in placenta leads to earlier placental damage, thus cytokine expression ensues earlier. This is consistent with a former study by Haider. ${ }^{5}$ Referring to the study by Robert JM and Hubel CA in 2009, the second stage of preeclampsia may occur even without the first stage, when maternal risk factors such as obesity and diabetes were clinically significant to generate clinical manifestations of preeclampsia syndrome. ${ }^{15}$ Founds reported an enhancement of TNF- $\alpha$ production by adipocytes in preeclamptic women. ${ }^{19}$

Further study including objective tests for kidney and liver function in TNF- $\alpha$ measurement, or investigating other factors to predict preeclampsia, is encouraged.

\section{CONCLUSION}

Serum level of PIGF in early-onset preeclampsia is lower than in late onset preeclampsia. There is no significant difference of TNF- $\alpha$ serum level between the early and late onset preeclampsia.

\section{REFERENCES}

1. Cunningham FG, Leveno KJ, Bloom SL, Hauth JC, Rouse Dj, Spoong CY. Implantation, Embryogenesis, And Placental Development. In: Williams Obstetrics. New York: McGraw-Hill 2010; 36-77.

2. Chang JJ, Muglia LJ, Macones GA. Association Of Early-Onset Preeclampsia In First Pregnancy With Normotensive Second Pregnancy Outcomes: A Population-Based Study. BJOG. 2010; 117(8):946-53.

3. Tranquilli AL, Landi B. The Origin Of Pre-Eclampsia: From Decidual "Hyperoxia" To Late Hypoxia. Med. Hypotheses. 2010; 75: 38-46.

4. Aris A, A AO, Moutquin JM, Leblanc S. Potential Biomarkers Of Preeclampsia Inverse Correlation Between Hydrogen Peroxide And No Early In Maternal Circulation And At Term In Placenta of Women With Preeclampsia. Placenta. 2009; 30:342-7.

5. Haider S, Knofler M. Human Tumour Necrosis Factor: Physiological and Pathological Roles in Placenta and Endometrium. Placenta. 2009; 30:111-23.

6. Huppertz B. Placental Origins of Preeclampsia Challenging the Current Hypothesis. Hypertension. 2008; 51:970-5.

7. Varughese B, Bhatla N, Kumar R, Dwivedi SN, Dhingra R. Circulating Angiogenic Factors In Pregnancies Complicated By Pre-Eclampsia. Nat Med J India. 2010; 23:233-8.

8. Kusanovic JP, Romero R, Chaiworapongsa T, Erezi O, Poodja M, Vaisbuch E. A Prospective Cohort Study of The Value Of Maternal Plasma Concentrations Of Angiogenic And AntiAngiogenic Factors In Early Pregnancy And Midtrimester In The Identification Of Patients Destined To Develop Preeclampsia. J Mater-Fet Neonat Med. 2009; 22(11):1021-38.

9. Levine RJ, Maynard SE, Qian C, Lim KH, England LJ, Yu KF. Circulating Angiogenic Factors and the Risk of Preeclampsia. N Engl J Med. 2004; 350:672-83.

10. Foidart JM, Munaut C, Chantraine F, Akolekar R, Nicolaides KH. Maternal Plasma Soluble Endoglin At 11-13 Weeks' Gestation In Pre-Eclampsia. Ultrasound Obstet Gynecol. 2010; 35:680-7.

11. Rinehart BK, Terrone DA, Lagoo-Deenadayalan S, Barber WH, Hale EA, Martin JN, et al. Expression of the Placental Cytokines Tumor Necrosis Factor $\alpha$, Interleukin $1 \beta$, and Interleukin 10 is Increased in Preeclampsia. Am J Obstet Gynecol. 1999; 181:915-20.

12. Muzamil S, Singhal U, Gulati R, Bano I. Serum Tumor Necrosis Factor a in Preeclampsia. Indian J Physiol Pharmacol. 2005; 49(2):236-40.

13. Serin YS, Ozcelik B, Baphud M, Kylyc H, Okur D, Erez R. Predictive Value of Tumor Necrosis Factor Alpha (TNF- $\alpha$ ) in Preeclampsia. Eur J Obstet Gynecol Reprod Biol. 2002; 100:143-5. 
14. Sanchez SE, Zhang C, Williams MA, Ware-Jauregui S, Larrabure G, Bazul V, et al. Tumor Necrosis Factor-a Soluble Receptor p55 (sTNFp55) and Risk of Preeclampsia in Peruvian Women. J Reprod Immunol. 2000; 47:49-63.

15. Roberts JM, Hubel CA. The Two Stage Model of Preeclampsia: Variations on the Theme. Placenta Trophoblast Research. 2009; 23:32-7.

16. Ogge G, Chaiworapongsa T, Romero R, Youssef H, Kusanovic JP, Yeo L. Placental Lesions Associated With Maternal Under perfusion Are More Frequent in Early-Onset Than in LateOnset Preeclampsia. J Perinat Med. 2011; 39(6):641-52.
17. Huppertz B. Placental Origins of Preeclampsia Challenging the Current Hypothesis. Hypertension. 2008; 51:970-5.

18. Hubel CA. Oxidative Stress in the Pathogenesis of Preeclampsia. Proc Soc Exp Biol Med. 1999; 222:222-35.

19. Founds SA, Powers RW, Patrick TE, Ren D, Harger GF, Markovic N, et al. A Comparison of Circulating TNF Alpha in Obese and Lean Woman with and without Preeclampsia. Hypertens Pregnancy. 2009; 27(1):39-48. 